\title{
Specification of Optic Nerve Oligodendrocyte Precursors by Retinal Ganglion Cell Axons
}

\author{
Limin Gao and Robert H. Miller \\ Department of Neurosciences, Case Western Reserve University, Cleveland, Ohio 44106
}

Cell fate commitment in the developing CNS frequently depends on localized cell-cell interactions. In the avian visual system the optic nerve oligodendrocytes are derived from founder cells located at the floor of the third ventricle. Here we show that the induction of these founder cells is directly dependent on signaling from the retinal ganglion cell (RGC) axons. The appearance of oligodendrocyte precursor cells (OPCs) correlates with the projection of RGC axons, and early eye removal dramatically reduces the number of OPCs. In vitro signaling from retinal neurites induces OPCs in responsive tissue. Retinal axon induction of OPCs is dependent on sonic hedgehog (Shh) and neuregulin signaling, and the inhibition of either signal reduces OPC induction in vivo and in vitro. The dependence of OPCs on retinal axonal cues appears to be a common phenomenon, because ocular retardation $\left(o r^{J}\right)$ mice lacking optic nerve have dramatically reduced OPCs in the midline of the third ventricle.

Key words: oligodendrocyte precursors; optic nerve; axon induction; sonic hedgehog; neuregulin; retinal ganglion cells

\section{Introduction}

During development the oligodendrocytes, the myelinating cells of the vertebrate CNS, are derived from founder cells that arise in spatially restricted regions of the ventricular zone. For example, in the spinal cord the ventral motor neuron progenitor (pMN) domain initially generates motor neurons and subsequently the oligodendrocyte precursor cells (OPCs) (Miller, 1996; Lu et al., 2000). The specification of this domain is a reflection of local sonic hedgehog $(S h h)$ signaling, and the generation of the different cell types reflects the concomitant action of a number of transcription factors, including oligodendrocyte type 2 (Olig2) (Lu et al., 2000; Zhou et al., 2000), neurogenin (Sommer et al., 1996; Perez et al., 1999), and neurokinin 2 transcription factorrelated 2 (Nkx2.2) (Briscoe et al., 1999; Soula et al., 2001; Zhou et al., 2001; Wordinger et al., 2002). The specification of motor neurons and OPCs is temporally distinct. Motor neurons arise several days before OPCs (Tanabe and Jessell, 1996), the specification of which depends on continued Shh (Orentas and Miller, 1996) and local Notch- $\delta$ mediated cell-cell interactions (Park and Appel, 2003). In the forebrain distinct subsets of oligodendrocytes also arise in specific domains and disperse widely (Kessaris et al., 2006), whereas optic nerve oligodendrocytes are derived from cells in the floor of the third ventricle (Small et al., 1987; Ono et al., 1997).

The mechanism of optic nerve OPC specification is unclear. Early in development the expression of $S h h$ by the prechordal mesoderm

Received Feb. 24, 2006; revised June 1, 2006; accepted June 1, 2006.

This work was supported by National Institutes of Health Grants NS 30800 and NS 36674 and the Myelin Repair Foundation. We thank Drs. C. Stiles and M. Qiu for reagents and Dr. A. Hall for helpful insights. We also thank R. Wang for technical assistance.

Correspondence should be addressed to Robert H. Miller, Department of Neurosciences, Case Western Reserve University, 2109 Adelbert Road, SOM E721, Cleveland, OH 44106. E-mail: rhm3@cwru.edu.

DOI:10.1523/JNEUROSCI.0855-06.2006

Copyright $\odot 2006$ Society for Neuroscience $\quad$ 0270-6474/06/267619-10\$15.00/0 contributes to the specification of ventral midline cells (Dale et al., 1997); however, OPCs arise later after eye development. In avians the retinal differentiation occurs at approximately stage 20 [embryonic day 3 (E3)] (Snow and Robson, 1994; Austin et al., 1995; McCabe et al., 1999), and retinal axons reach the forebrain at approximately stages 27-29 (E5-E6) (Halfter, 1987), concomitant with the initial appearance of OPCs (Ono et al., 1997).

Axons express molecular cues important in the induction of OPCs. In Drosophila, retinal axon-derived hedgehog triggers neurogenesis in the brain visual centers (Huang and Kunes, 1996). Likewise, avian ganglion cells express Shh (Spence and Robson, 1989; Prada et al., 1992; McCabe et al., 1999; Zhang and Yang, 2001), whereas rat retinal ganglion cell (RGC) axon-derived $S h h$ promotes astrocyte proliferation (Wallace and Raff, 1999). Neuregulin-1, important in Schwann cell and oligodendrocyte development (Canoll et al., 1996, 1999; Gassmann and Lemke, 1997; Vartanian et al., 1999), also is expressed by RGCs (Meyer and Birchmeier, 1994; Bermingham-McDonogh et al., 1996) and promotes the survival of optic nerve oligodendrocytes (Fernandez et al., 2000) and thickness of PNS myelin (Michailov et al., 2004).

Here we demonstrate that the appearance of chick OPCs in the floor of the third ventricle is correlated temporally with and dependent on retinal axon projection to the brain. Retinal axons can induce OPCs in vitro, and in vivo the retinal axons are required for the appearance of optic nerve OPCs. Axonal induction of OPCs is dependent on Shh and neuregulin and is not restricted to the chick visual system. The ocular retardation mutant $\left(\right.$ or $\left.^{J}\right)$ mice (Burmeister et al., 1996), which lack an optic nerve, have dramatically reduced numbers of OPCs at the floor of the third ventricle.

\section{Materials and Methods}

Embryos and surgery. Fertilized White Leghorn chicken eggs (Squire Valley View Farms, Cleveland, OH) were incubated and staged. To generate eyeless animals, we windowed stages 18-21 (E3) eggs and removed both 
of the eyes of the embryos with forceps. Then the eggs were taped and returned to the incubator until the desired developmental stage.

or ${ }^{J}$ mice. The $o r^{J}$ mice were obtained from The Jackson Laboratory (Bar Harbor, ME). The genotypes of the animals were determined as described previously (Burmeister et al., 1996).

Lipophilic dye labeling. To identify unambiguously the source of axons that associated with OPCs in the floor of the third ventricle, we labeled optic axons from one eye with the lipophilic dye 1, $1^{\prime}$-dioctadecyl-3,3,3',3'tetramethylindocarbocyanine perchlorate (DiI). A small cut was made in one stage 27 (E5) chicken retina, and DiI crystals were inserted into the eyeball. The eggs were taped and returned to the incubator until stage 31 (E7). Embryos were fixed with $4 \%$ paraformaldehyde (PFA), and coronal sections were cut on a vibratome (VT 1000S; Leica, Nussloch, Germany). Sections were labeled with monoclonal antibody $(\mathrm{mAb}) \mathrm{O} 4$, and coincident localization of $\mathrm{O}^{+}$cells and DiI-labeled axons was examined.

Cyclopamine and anti-neuregulin antibody injection. To inhibit putative signaling via the hedgehog pathway, we dissolved cyclopamine (Toronto Research Chemicals, Toronto, Ontario, Canada) in 45\% (w/v) 2-hydroxypropyl$\beta$-cyclodextrin (HBC; Sigma-Aldrich) in PBS and mixed it with $0.9 \%$ sodium chloride solution at $1: 1$ for injection. Stage 12 eggs were windowed, and $70 \mu \mathrm{l}$ of either cyclopamine/HBC/ $\mathrm{PBS} / 0.9 \% \mathrm{NaCl}$ or $\mathrm{HBC} / \mathrm{PBS} / 0.9 \% \mathrm{NaCl}$ was placed on top of the embryos from stage 19 to stage 29 (E2-E6). Similarly, embryos were exposed to anti-neuregulin (anti-NRG) antibody (Santa Cruz Biotechnology, Santa Cruz, CA) from stage 21 to stage 29 (E3-E6). Embryos were killed at stage 29 (E6) or stage 31 (E7). NRG expression was assayed by Western blotting according to standard protocols (Brady-Kalnay et al., 1995). Anti- $\beta$-actin (Santa Cruz Biotechnology) antibody was used as a loading control.

Explant and cell cultures. For explant cocultures the stage 24 (E4) chick spinal cords were isolated as previously described (Orentas et al., 1999) and divided into dorsal and ventral regions. Age-matched retinas were dissected, and explants were prepared. Explants were positioned at different distances apart and grown in growth factor-depleted Matrigel matrix (BD Biosciences, San Jose, CA) in DMEM/F-12 medium containing $10 \mathrm{ng} / \mathrm{ml}$ platelet-derived growth factor (PDGF), 0.5\% FBS-C, N2 supplement, and L-glutamine. After 3-5 d the cultures were fixed with $4 \%$ $\mathrm{PFA}$ and labeled with $\mathrm{mAb} \mathrm{O} 4$.

For cocultures of dissociated cells and explants stage 24 (E4) chick retinal explants were grown on coverslips coated with poly-L-lysine and laminin for $2 \mathrm{~d}$; dorsal spinal cord cells from stage 24 (E4) quails were added at a density of $2.0 \times 10^{5}$ cells/coverslip (Miller et al., 1997) and grown for $4 \mathrm{~d}$. Cultures were labeled with $\mathrm{mAb} \mathrm{O} 4$ and quail cell-specific perinuclear antigen (QCPN; Developmental Studies Hybridoma Bank, University of Iowa, Iowa City, IA).

For conditioned medium the stage 24 chick retinal explants were grown in DMEM/F-12 containing 0.5\% FBS-C, N2 supplement, and L-glutamine for $72 \mathrm{~h}$. Media were filtered and used at a 1:1 ratio with fresh DMEM/F-12 medium containing $10 \mathrm{ng} / \mathrm{ml}$ PDGF, N2 supplement, and L-glutamine for dissociated cell cultures. 5E1 antibody (Developmental Studies Hybridoma Bank) and anti-NRG antibody were added to the culture. Cyclopamine (Toronto Research Chemicals) was dissolved in DMSO and added to explants or dissociated cell cultures at the time of plating.

Compartmentalized explant cocultures were established as described by Campenot (1977). Stage 24 chick retina explants were plated into the center compartment for 2-3 weeks until the RGCs extended their axons to the side chambers. Stage 24 chick dorsal spinal cord explants were added to the side chambers and grown for another $4 \mathrm{~d}$. To ensure that there was no leakage of medium between compartments, we added ${ }^{32} \mathrm{P}$ to the center compartment. At $1 \mathrm{~h}$ later the media in the side compartments were assayed for radioactivity. Those cultures without leakage were fixed with $4 \%$ PFA and labeled with mAb O4.

In situ hybridization and immunohistochemical staining. Stages 26-27 (E5) and stage 31 (E7) chick embryos were decapitated and fixed with $4 \%$ PFA in phosphate buffer (PB) at $4^{\circ} \mathrm{C}$ and transferred to $30 \%$ sucrose in $\mathrm{PB}$ overnight. Sections were labeled and photographed as previously described (Ono et al., 1995). In situ hybridization (ISH) of Shh was performed at $72^{\circ} \mathrm{C}$ as described previously (Schaeren-Wiemers and Gerfin-Moser, 1993) with minor modifications. For ISH of neuregulin the RNA probes corresponding to the full-length pro-acetylcholine receptor-inducing activity-1 (pro-ARIA-1) $2.3 \mathrm{~kb}$ sequence (Loeb et al., 1999 ) were used, and the hybridization was performed at $52^{\circ} \mathrm{C}$.

For immunofluorescent staining the whole brain and optic nerves were dissected, fixed with $4 \% \mathrm{PFA}$, embedded in $5 \%$ agar, and sectioned at $50-80 \mu \mathrm{m}$ on a vibratome. Sections were collected in PBS and labeled with mAb O4, anti-Patched (Santa Cruz Biotechnology), and Nkx2.2 (Developmental Studies Hybridoma Bank) as described previously (Ono et al., 1995).

\section{Results}

The appearance of optic nerve OPCs correlates with retinal projection

Optic nerve oligodendrocytes develop from cells in the floor of the third ventricle directly dorsal to the optic chiasm. These cells or their progeny then populate the optic nerve before differentiating and myelinating (Ono et al., 1997). To determine whether the appearance of OPCs at the midline of the third ventricle correlates with retinal axon growth to the chiasm, we labeled sections of chick embryos with mAb O4 and $N k x 2.2$, markers of OPCs, and mAb 8A2 that identifies an antigen selectively expressed on RGC axons (Drazba et al., 1991). As in spinal cord, O4 specifically identifies chick optic nerve OPCs as demonstrated by the complete loss of $\mathrm{O}^{+}$ oligodendrocytes after $\mathrm{O} 4$ complement lyses, the coincident expression of $\mathrm{O} 4$ and $\mathrm{O} 1$, and the $>98 \%$ appearance of $\mathrm{O}^{+}$ 
control
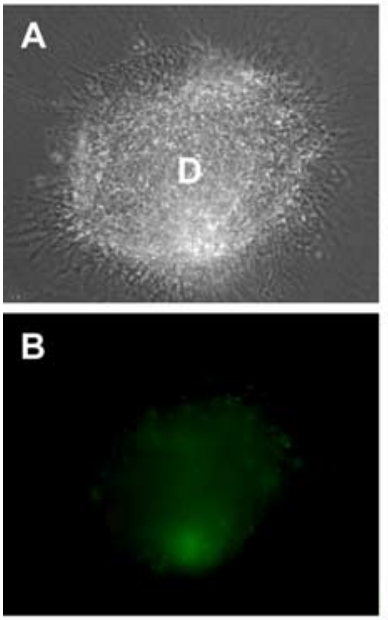

control
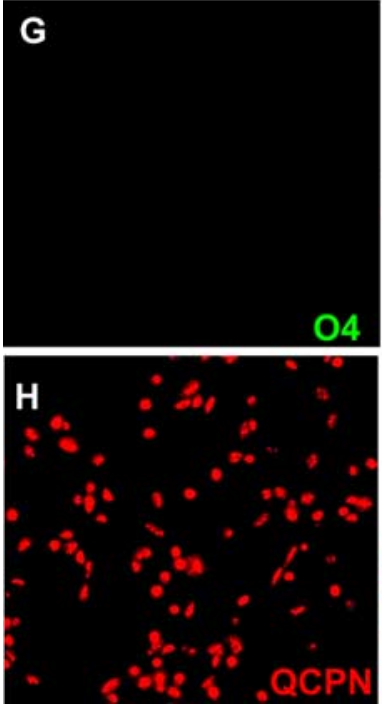
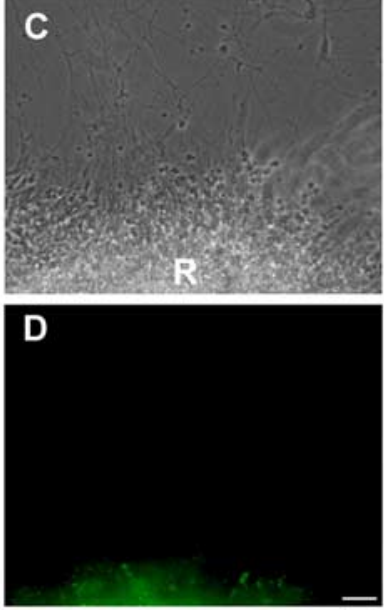

co-culture
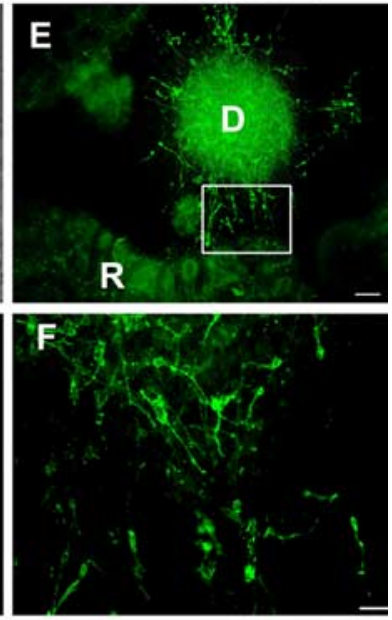

co-culture
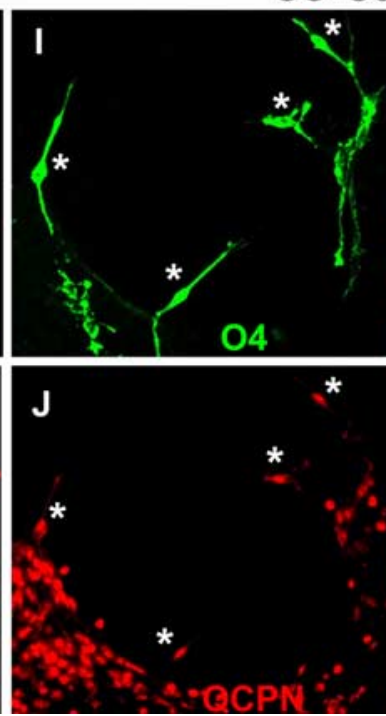
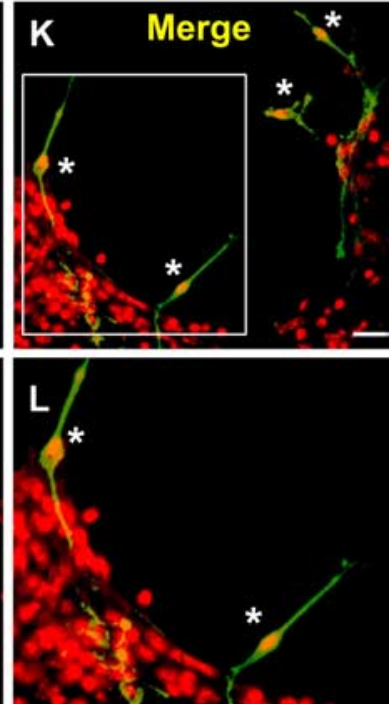

Figure 2. Retinal cues are capable of inducing OPCs in responsive tissue. In isolation, neither stage 24 (E4) dorsal spinal cord ( $\boldsymbol{A}_{\text {, }}$ B) nor retinal explants $(\boldsymbol{C}, \boldsymbol{D})$ generated significant numbers of $04{ }^{+} \mathrm{OPCs}$ after $4 \mathrm{~d}$. In contrast, in spinal cord/retina cocultures significant numbers of OPCs developed after $3-5 \mathrm{~d}(\boldsymbol{E})$. $\boldsymbol{F}$, High magnification of boxed inset in $\boldsymbol{E}$. $\boldsymbol{G}-\boldsymbol{L}$, Cocultures of chick retina with quail dorsal spinal cord cells demonstrated spinal cord, not retina, as the OPC source. In isolation, quail dorsal spinal cord cells did not generate $\mathrm{OPC}$, although all of the cells were labeled with $m A b Q C P N(\boldsymbol{G}, \boldsymbol{H})$. In coculture with chick retinal explants for $4 \mathrm{~d}$, many $04^{+}$cells developed $(\boldsymbol{I})$, and all of these were quail-derived, as shown by QCPN labeling (asterisks) $(\boldsymbol{J}-\boldsymbol{L}$ ). $\boldsymbol{L}$, High magnification of boxed inset in $\boldsymbol{K}$. D, Dorsal spinal cord; R, retinal-derived tissue. Scale bars: $\boldsymbol{A}-\boldsymbol{D}, 50 \mu \mathrm{m} ; \boldsymbol{E}, 100 \mu \mathrm{m} ; \boldsymbol{F}, 200 \mu \mathrm{m} ; \boldsymbol{G}-\boldsymbol{L}$, $100 \mu \mathrm{m}$.

oligodendrocytes in pan-purified $\mathrm{O}^{+}$cultures (Ono et al., 1995). The earliest OPCs were detected in the floor of the third ventricle at approximately stage 27 (E5), $\sim 1 \mathrm{~d}$ after retinal axons grew into and through the optic nerve (Rager, 1980). At stage 31 (E7) 8A2 labeling was detected in the optic nerve, optic chiasm, and optic tract (Fig. 1A). At the floor of the third ventricle the retinal axons closely apposed the $\mathrm{O}^{+} / \mathrm{Nk} \times 2.2^{+}$ OPCs (Fig. $1 B, C$ ), suggesting that cues from retinal axons contributed to the induction of OPCs in this region. To define more closely the spatial associations between retinal axons and ventricularly located OPCs, we labeled one eye with DiI at stage 27 (E5) and killed the embryos at stage 31 (E7). Sections at the level of the optic chiasm (Fig. 1D-F) demonstrated RGC axons directly below the midline of the third ventricle and in close proximity to ventricular $\mathrm{O} 4{ }^{+}$OPCs.
Retinal cues induce

oligodendrocyte precursors

To determine whether the retina was capable of inducing OPCs, we grew retinal explants in isolation or cocultured them with inducible tissue derived from embryonic dorsal spinal cord (Orentas et al., 1999). In isolation, neither stage 24 retinal ( 24 of 24 ) explants nor the majority ( $84 \%)$ of dorsal spinal cord explants ( 65 of 77 ) gave rise to significant numbers of oligodendrocytes (Fig. $2 A-D$ ). In contrast, in retinal/spinal cord cocultures after 3-5 d many $\mathrm{O}^{+}$ OPCs were detected that were associated predominantly with the dorsal spinal cord explants (65 of 66) (Fig. 2E,F). The induction of OPCs was dependent on the spatial separation of the explants. When dorsal explants were within $400 \mu \mathrm{m}$ of retinal explants, $80 \%$ (39 of 49 ) contained $10-100$ OPCs, whereas beyond $800 \mu \mathrm{m}$ just $25 \%$ (1 of 4) contained any OPCs. Because of the close proximity of the explants and the highly migratory behavior of OPCs (Small et al., 1987), the origin of the induced cells was unclear. To define unambiguously the source of OPCs, we double-labeled cocultures of chick retinal explants and quail dorsal spinal cord cells with $\mathrm{mAb} \mathrm{O} 4$ and the quail-specific marker QCPN (Burns and Douarin, 1998). When quail dorsal spinal cord cells were cultured alone for $4 \mathrm{~d}$, no $4^{+}$cells were detected, although all of the cells were QCPN ${ }^{+}$(Fig. 2G,H). In contrast, in retina/spinal cord cocultures substantial numbers of OPCs developed (Fig. $2 I-L$ ), and all of the $\mathrm{O}^{+}$OPCs were derived from $\mathrm{QCPN}^{+}$dorsal spinal cord cells. These studies indicate that signals from developing retina are competent to induce oligodendrocyte precursors in responsive tissue.

\section{Retinal neurites induce OPCs in vitro}

The induction of OPCs by retina may reflect the secretion of soluble cues from neuronal cell bodies and/or signaling by axons. To test the capacity of axons to induce oligodendrocytes in vitro, we plated retinal explants in the central chamber of compartmentalized cultures, and their processes were allowed to grow into the lateral chambers (Fig. $3 A$ ). Oligodendrocyte-inducible stage 24 (E4) dorsal spinal cord explants were added to lateral chambers, and the cocultures were grown for an additional $4 \mathrm{~d}$ before being labeled with $\mathrm{mAb} \mathrm{O} 4$. In the absence of retinal explants $>70 \%$ of spinal cord explants contained no $4^{+}$cells ( 36 of 47 ), and $\sim 17 \%$ of explants ( 8 of 47) contained between 1 and 10 cells (Fig. 3D). In contrast, in the presence of retinal neurites $100 \%$ of spinal cord explants (51 of 51) contained $\mathrm{O}^{+}$cells and $>90 \%$ ( 47 of 51 ) had $>10 \mathrm{O} 4^{+}$cells (Fig. $3 B-D$ ). The induction of OPCs in lateral chambers was not a result of diffusion of cues from the central chamber, because no mixing of media was detected in 22 of 25 compartmental cultures via ${ }^{32} \mathrm{P}$ analyses. The relative distribution of OPCs and axon bun- 

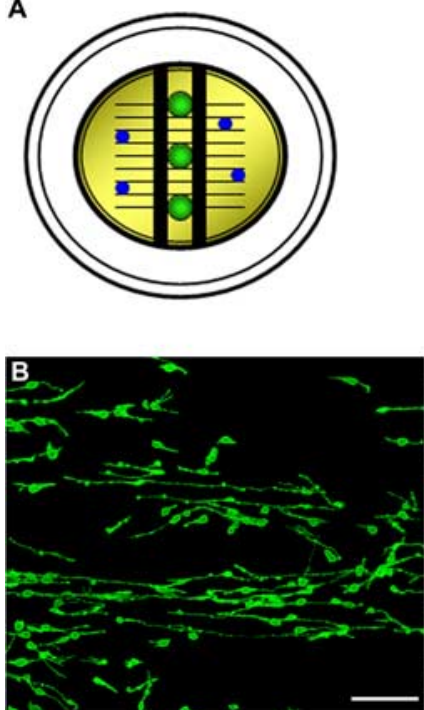

D
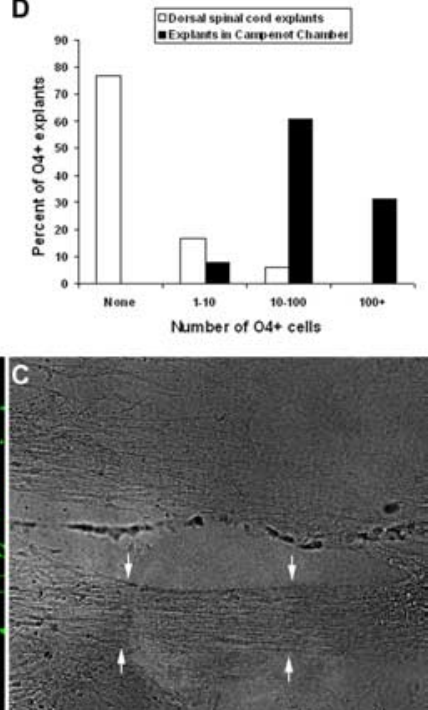

Figure 3. Retinal neurites are capable of inducing OPCs. $\boldsymbol{A}$, To determine whether retinal axons had OPC inductive properties, we grew retinal explants in the central compartment of Campenot chambers and cultured them for $14 \mathrm{~d}$ to allow neurites to grow to the side chambers. $B, C$, Dorsal spinal cord explants (stage 24; E4) were added to the side chambers and labeled with $\mathrm{mAb} 04$ after $4 \mathrm{~d}$. In regions rich in neurites (between arrows), many $04^{+}$cells developed that were oriented along the neurites $(\boldsymbol{B}) \cdot \boldsymbol{D}$, Quantification of $04^{+}$cell numbers demonstrated a robust induction of $\mathrm{OPCS}$ by retinal neurites. Data represent the total number of explants containing different numbers of $04^{+}$cells in each condition $(n=47$ and 51 explants for control and experimental, respectively, from 3 different preparations). Scale bar (in $\boldsymbol{B}$ ), $100 \mu \mathrm{m}$.

dles in lateral compartments suggested that neurite induction was highly localized. Explants not directly associated with neurites contained fewer OPCs, and in some cases only regions of the explant adjacent to neurites contained OPCs (Fig. $3 B, C$ ).

\section{Retinal projections are required for OPC appearance in the floor of the third ventricle}

The correlation of OPC appearance and axonal projections combined with the ability of RGC neurites to induce OPCs in vitro suggests a model in which the appearance of optic nerve OPCs is a consequence of RGC axon growth to the brain. To determine whether RGC axons were required for OPC appearance, we removed one or both eyes from chick embryos at stage 21 (E3) before the majority of axons had grown to the brain (Trousse et al., 2001) and the effects on OPC appearance had been assayed. Eye removal did not significantly compromise embryo viability up to stage 37 (E11) (Fig. 4A,B), and OPC development was compared at stage 31 (E7), several stages after their normal initial appearance (Ono et al., 1997). Control embryos contained $>300$ $\mathrm{O}^{+}{ }^{+}$OPCs per embryo (Fig. $4 C$ ) in the floor of the third ventricle. These cells were not distributed uniformly along the rostrocaudal axis. A peak of cells ( $\sim 80$ cells) correlated with the center of the optic nerve (Fig. $4 J$ ). After unilateral eye removal the OPCs were localized similarly, although the number was reduced slightly. In contrast, in eyeless animals the total number of OPCs per embryo was reduced by $>65 \%$ (300 control vs 100 experimental; $n=6$ ) (Fig. 4D), and the distribution shifted caudally (Fig. $4 J$ ). The reduction in cell number in eyeless animals was consistent with a requirement for optic axons in OPC induction, although eye removal resulted in morphological changes in the floor of the third ventricle (Fig. 4, compare $C, D$ ). To assess whether the lack of OPCs in eyeless animals reflected secondary tissue perturbation or a lack of cell specification, we established explants from the third ventricle midline of E6 control and eyeless embryos, and the number of OPCs was quantified after $2 \mathrm{~d}$ in vitro. In control cultures $(n=3)>70 \%$ of explants contained between 10 and $100 \mathrm{O}^{+}$cells, and the remainder contained $>100$ OPCs (Fig. $4 F, G, K$ ). Removal of one eye resulted in a slight reduction in the number of OPCs that developed. For example, $>70 \%$ of control explants, but only $36 \%$ of one-eyed animal explants, contained between 10 and 100 OPCs (Fig. 4 K). Explants derived from eyeless animals developed significantly fewer OPCs than controls. The proportion of explants lacking OPCs increased from 0 in control to $15 \%$ in eyeless animals. More significantly, $\sim 35 \%$ of eyeless explants contained $<10$ OPCs, and only $8 \%$ contained $>100$ OPCs (Fig. $4 H, I, K$ ). Together, these data strongly suggest a requirement for retinal axons in optic nerve OPC appearance. The influence of RGCs was localized to the floor of the third ventricle. Oligodendrocyte precursors in the lateral domains of the third ventricle were unaffected in eyeless animals (Fig. 4E).

\section{Retinal induction of OPCs in vitro is dependent on Shh signaling}

In the spinal cord ventrally derived oligodendrocytes are dependent on Shh signaling, whereas a subpopulation of dorsally derived OPCs is Shh-independent (Chandran et al., 2003; Cai et al., 2005; Vallstedt et al., 2005). To address whether the retinal induction of optic nerve OPCs was dependent on hedgehog $(h h)$, we assayed the effect of cyclopamine, an inhibitor of $h h$ signaling (Stone et al., 1996). Retinal conditioned medium increased fourfold the number of OPCs that developed in dorsal spinal cord cultures (Fig. 5A-D). This inductive activity was inhibited completely by the addition of cyclopamine (Fig. 5E,F). Similarly, OPC induction by retinal coculture was inhibited by cyclopamine such that $47 \%$ of spinal cord explants lacked OPCs, with residual cells seen only in those explants most closely apposed to retinal explants (Fig. $5 \mathrm{H}-J$ ). More critically, the ability of retinal neurites to induce oligodendrocytes in compartmental chambers also was blocked by the addition of cyclopamine (Fig. $5 K-M$ ). For example, although $>90 \%$ of spinal cord explants contained $>10$ OPCs in the presence of retinal neurites, only $2 \%$ of explants contained $>10$ cells in the parallel cultures grown in the presence of cyclopamine. These data suggest that retinal induction of OPCs is mainly dependent on $h h$ signaling but do not define the specific member of the $h h$ family. To address whether this induction was mediated by $S h h$, we repeated the experiments in the presence of mAb 5E1 specifically to block Shh. As with cyclopamine treatment, retinal induction of oligodendrocytes essentially was eliminated by function blocking the $5 \mathrm{E} 1$ treatment in a concentration-dependent manner, indicating a dependence on Shh signaling (Fig. 5G).

\section{Induction of OPCs in vivo requires Shh signaling}

The ability of 5E1 to block retinal induction of OPCs in vitro suggested that $S h h$ may be required in vivo for the specification of optic nerve OPCs as well as in earlier neural patterning events (Dale et al., 1997; Orentas et al., 1999; Nery et al., 2001; Soula et al., 2001). To distinguish between early and late Shhdependent events, we injected embryos with cyclopamine starting at stage 19 (E2), a time during normal development when Shh expression is lost from the prechordal mesoderm and becomes restricted to the notochord caudal to the forelimbs (Dale et al., 1997), until stage 29 (E6) and killed them at stage 31 (E7) when $\mathrm{O}^{+}$OPCs are clearly detectable at the ventral midline of the third ventricle (Ono et al., 1997). The 

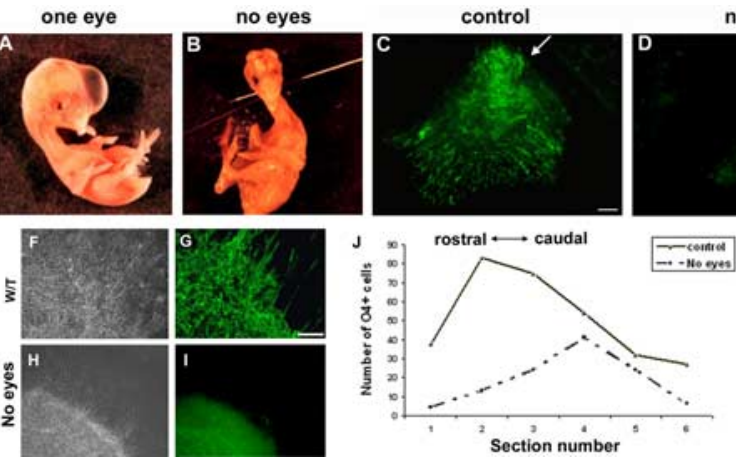

no eyes
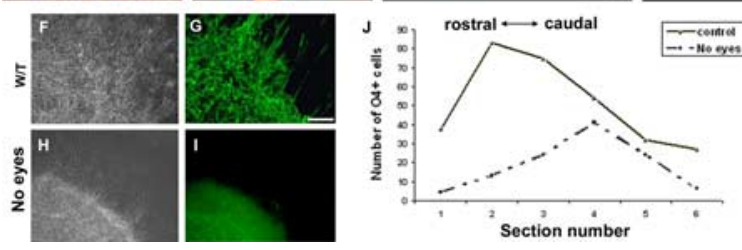

Figure 4. Retinal projections are required for OPC induction at the third ventricle midline. One $(\boldsymbol{A})$ or both $(\boldsymbol{B})$ eyes were removed from embryos at stage 21 (E3), and the animals were allowed to develop until stage 31 (E7). In control animals, many $04{ }^{+}$OPCs were present at the third ventricle floor (arrow) at E7 (C) but were absent or greatly reduced (arrow) in eyeless animals (D). $\boldsymbol{E}, 04^{+} \mathrm{OPCs}$ in the lateral region of the third ventricle were not affected by the removal of both eyes. $\boldsymbol{F}, \boldsymbol{G}$, The residual OPCS in the floor of the third ventricle were located more caudally in eyeless animals. $\boldsymbol{H}, \boldsymbol{I}$, Explants derived from the floor of the third ventricle of eyeless animals at stage 29 (E6) demonstrated a reduced ability to generate OPCs after $48 \mathrm{~h}$ in vitro. J, Quantification of $\mathrm{O4}^{+}$cell numbers demonstrated a significant reduction of $04^{+}$cells in the floor of the third ventricle in eyeless animals. $\boldsymbol{K}$, Comparison of OPC development in control and eyeless animals. Although all control explants contained $>100 P C s, 50 \%$ of explants from eyeless animals had $\angle 100 P C$. Data represent the proportion of explants containing different cell numbers from three different preparations. Scale bars: $\boldsymbol{C}-\boldsymbol{E}, 25 \mu \mathrm{m} ; \boldsymbol{F}-\boldsymbol{I}, 50 \mu \mathrm{m}$.

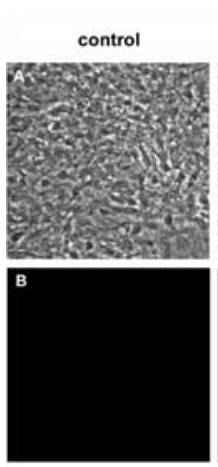

control

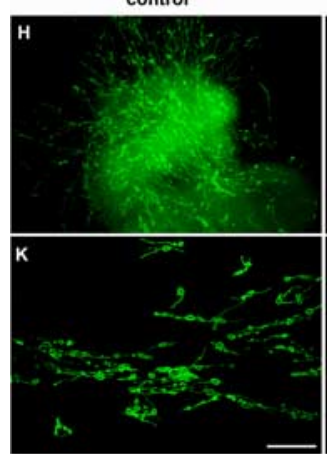

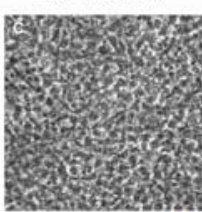

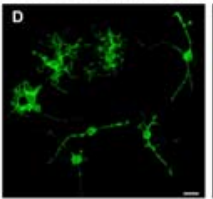

with cyclopamine

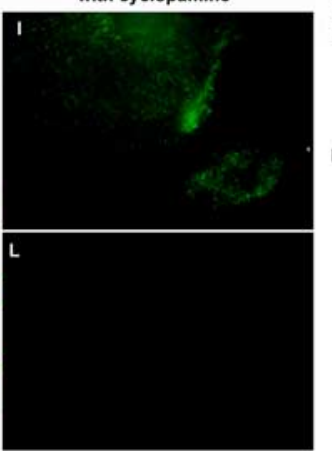

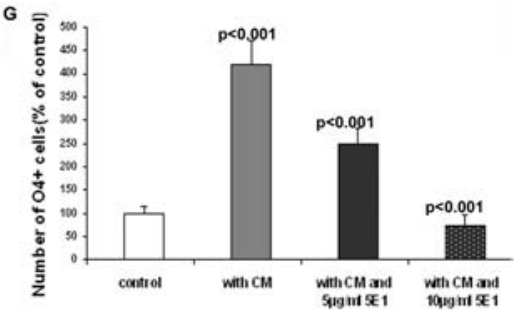

J
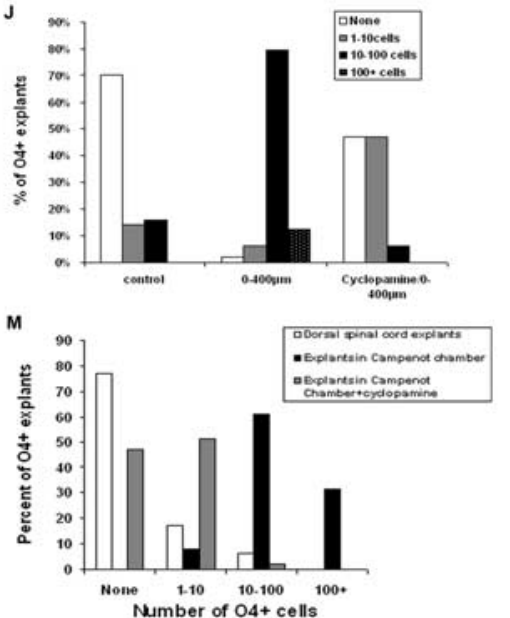

Figure 5. Retinal induction of $O P C S$ is dependent on hedgehog signaling. $\boldsymbol{A}-\boldsymbol{F}$, Stage 24 (E4) retinal explant conditioned medium induces $0 P C$ in stage 24 (E4) dorsal spinal cord cells after 4 d. $\boldsymbol{A}, \boldsymbol{B}$, Control cultures containing few OPCs. C, D, Retinal CM induces significant numbers of OPCs. $\boldsymbol{E}, \boldsymbol{F}$, This induction is inhibited by treatment with cyclopamine. $\boldsymbol{G}$, Quantification of $04^{+}$ cells in cultures treated with Shh function-blocking mAb 5E1 shows that the induction is inhibited in a dose-dependent manner. Error bars represent SD (3 different preparations). $\boldsymbol{H}, \boldsymbol{I}$, In cocultures of retinal and dorsal spinal cord explants, the induction of OPCS is reduced significantly by cyclopamine treatment. J, Quantification of $04^{+}$cells in control cocultures and cocultures treated with cyclopamine. $\boldsymbol{K}, \boldsymbol{L}$, Likewise, the inductive capacity of retinal neurites in the Campenot chambers is blocked by the addition of cyclopamine to the lateral chamber. $\boldsymbol{M}$, Quantification of $04^{+}$cells in Campenot chambers. Scale bars (in $\boldsymbol{D}, \boldsymbol{K}$ ), $50 \mu \mathrm{m}$. blocked OPC induction in both the floor and lateral aspects of ventricle, suggesting that in both regions the majority of OPCs was Shh-dependent (Fig. 6A,B). The morphology of cyclopamine-treated animals was altered slightly, with a thickening of the ventral and ventrolateral wall of the third ventricle (Fig. $6 B$ ) that indirectly might inhibit OPC induction. To circumvent the effect of such secondary patterning, we compared OPC development in explants derived from the ventricular midline of E6 control and cyclopamine-treated animals. In controls all explants contained significant numbers of OPCs, with $\sim 70 \%$ ( 43 of 63 ) having $>100 \mathrm{O}^{+}{ }^{+}$cells after $48 \mathrm{~h}$ (Fig. $6 C, D, I)$. In contrast, $>85 \%$ of cyclopamine-treated explants lacked $\mathrm{O} 4^{+}$cells, and only two of 76 explants had $>100$ cells (Fig. $6 E, F, I$ ). These data demonstrate a requirement for $h h$ in the normal development of optic nerve OPCs. To define the timing of Shh signaling, we incubated isolated explants with cyclopamine after removal from control animals at stage 27 (E5), and the development of OPCs was assayed. The reduction in OPC numbers, although significant $(11.8 \%$ as compared with $36.6 \%$ control explants contained $100+$ OPCs), was less dramatic than that seen in animals that received cyclopamine injections for $4 \mathrm{~d}$ (Fig. 6G, $H, J$ ). Together, these data demonstrate that induction of optic nerve OPCs is dependent on continued $S h h$ signaling after the initial patterning of rostral CNS.

\section{Shh expression at the third ventricle} floor is derived from retinal projections The expression of Shh was correlated spatially and temporally with optic nerve axonal growth to the optic chiasm. Labeling of coronal sections of stage 31 (E7) animals with $\mathrm{mAb} 5 \mathrm{E} 1$ demonstrated labeling at the floor of the third ventricle associated with the optic chiasm as well as in more lateral ventricular regions (Fig. $6 \mathrm{~K}$ ). Removal of both eyes resulted in a loss of Shh labeling in the region of the third ventricle floor while lateral labeling was retained (Fig. 6L), suggesting that the ventral expression of Shh depended on optic axon projections. To determine whether the ventral $S h h$ was induced locally by RGC axons or was derived from RGC axons, we performed Shh ISH on coronal sections. At induction of $\mathrm{O}^{+}{ }^{+}$cells was reduced dramatically in animals exposed to cyclopamine. Although control animals contained $300+$ OPCs, cyclopamine-treated animals had $<25$ (Fig. $6 A, B)$. In contrast to eye removal that selectively inhibited OPCs in the floor of the third ventricle, cyclopamine injection stage 27 (E5) Shh expression was detected in only the lateral ventricular regions, but not the floor of the third ventricle at the chiasmal level (Fig. 6N), although expression was detected in more caudal sections without optic nerve (data not shown). At stage 31 (E7) Shh mRNA expression was similar (Fig. 6O) and was 
unaltered by removal of both eyes at stage 21 (E3) (Fig. 6P), indicating that Shh was not induced locally by, but derived from, RGC axons. To determine the location of Shh-responding cells, we labeled sections of stage 31 (E7) embryos with antibodies to the Shh binding protein Patched. Patched labeling was distributed widely in the ventral and lateral ventricular regions of the third ventricle, with particularly strong expression in the floor of the third ventricle (Fig. 6M) coincident with the expression of Shh.

\section{Retinal-derived neuregulin is required} for normal optic nerve OPC appearance Neuregulin-1 has been implicated in OPC development and is expressed by RGCs (Bermingham-McDonogh et al., 1996; Vartanian et al., 1999; Fernandez et al., 2000). To determine whether retinal induction of OPCs is dependent on NRG, we tested the effect of function-blocking antiNRG antibody. Retinal conditioned medium induced a fourfold to fivefold increase in spinal cord cultures, and this induction was inhibited significantly by the addition of anti-NRG antibody (Fig. $7 A-F, G)$, suggesting that retinal-derived neuregulin contributed to the appearance of OPCs. To determine whether neuregulin was involved in vivo, we assayed its expression in the third ventricle floor and associated optic chiasm region in normal and eyeless animals by ISH and Western blot analyses. NRG mRNA was not detected in the floor of the third ventricle and optic chiasmal region when we used a fulllength chicken pro-ARIA probe (Loeb et al., 1999). In contrast, Western blot analyses showed that in normal animals the NRG protein was expressed strongly at stage 29 (E6), and this expression was reduced significantly in eyeless embryos (Fig. $7 J$ ), suggesting that retinal axons are the source of NRG expression in this region. To determine whether NRG is required for optic nerve OPC appearance in vivo, we injected function-blocking antiNRG antibody into chick embryos daily from stage 21 to stage 29 (E3-E6). Quantification of OPCs at stage 31 (E7) demonstrated a significant reduction of OPCs in anti-NRG antibody-treated animals, consistent with a requirement for NRG in optic nerve OPC development (Fig. 7 I, J).

\section{Retinal axonal requirement for murine optic nerve OPC induction}

To determine whether retinal axons are required for OPC development in other species, we assayed the or mice that have mutations in the Chx10 gene leading to
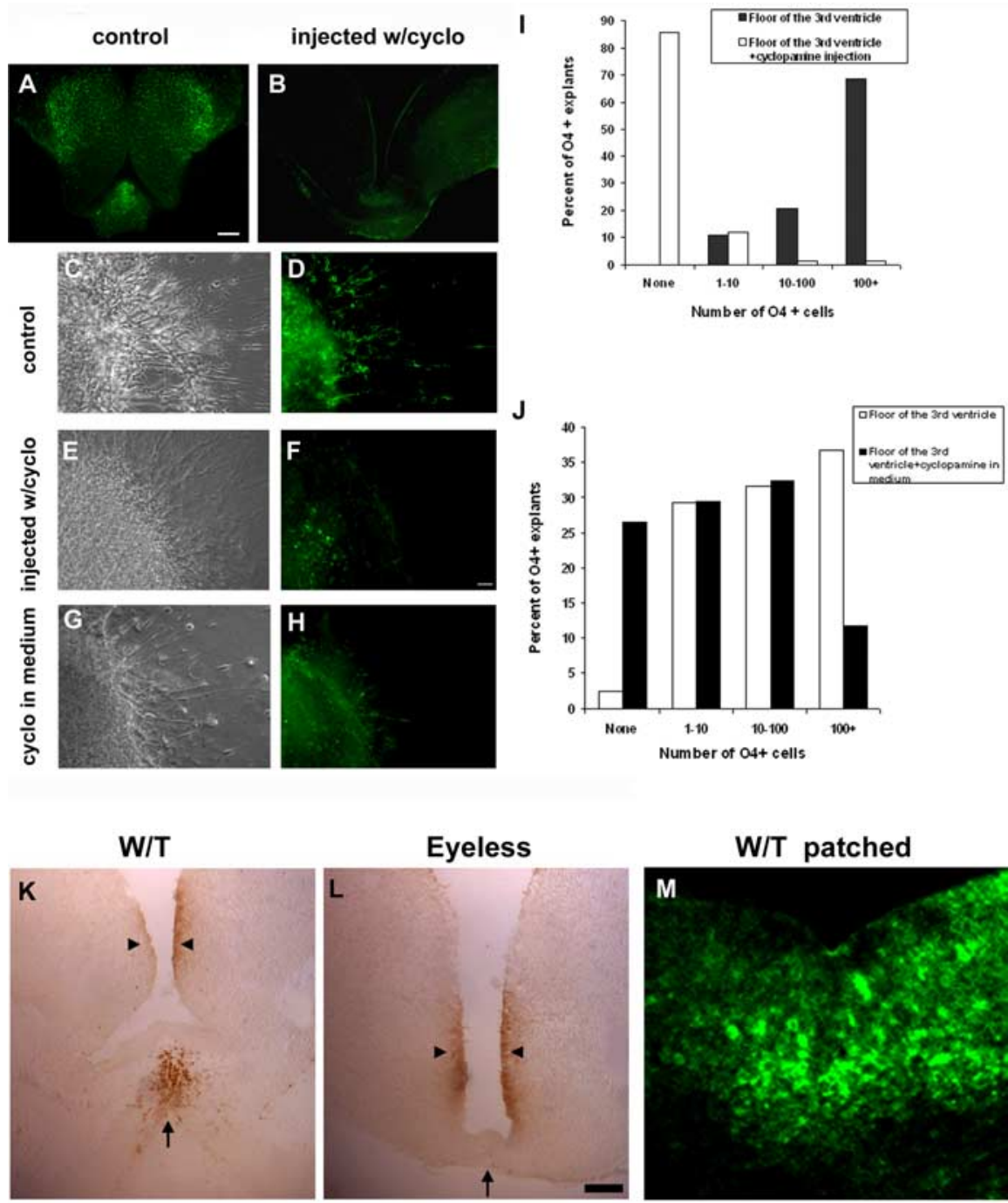

E5 W/T
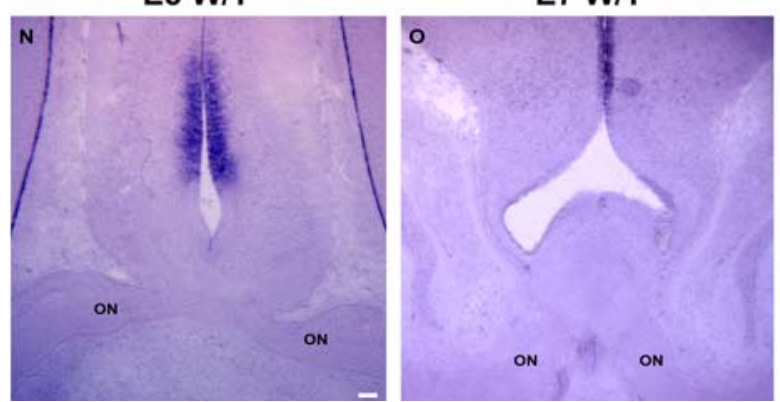

E7 Eyeless

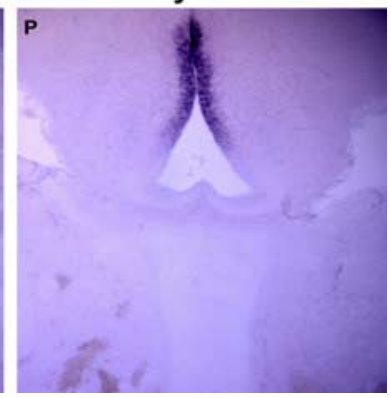

Figure 6. Appearance of OPCS at the midline of the third ventricle is blocked by cyclopamine treatment, and localized Shh expression is absent in eyeless animals. $\boldsymbol{A}, \boldsymbol{B}$, Exposure to cyclopamine between stage 21 (E3) and stage 29 (E6) inhibited the normal development of OPCs lining the third ventricle. $\mathbf{C}-\boldsymbol{H}$, Explants derived from the third ventricle floor developed reduced numbers of $04^{+}$cells after cyclopamine exposure. Shown are control explants $(\boldsymbol{C}, \boldsymbol{D})$, explants from cyclopamine-injected animals $(\boldsymbol{E}, \boldsymbol{F})$, and explants exposed to cyclopamine in vitro $(\boldsymbol{G}, \boldsymbol{H}) . \boldsymbol{I}$, Quantification of OPCs in explants from animals exposed to cyclopamine. J, Quantification of OPCS in explants treated with cyclopamine after removal from the naive animals. The reduction in OPC number was greater in explants from animals exposed to cyclopamine $(\boldsymbol{I})$ than in explants treated with cyclopamine after removal $(\boldsymbol{J})$, suggesting that OPC induction occurred before explant establishment. $\boldsymbol{K}$, Shh is detectable by mAb 5E1 staining in the chiasmal region (arrow) of the optic nerve only in the presence of optic nerve axons. $L$, In eyeless animals, the labeling is lost, although it is retained in lateral aspects of the third ventricle (arrowhead). $\boldsymbol{M}$, Expression of patched is detected at the floor of the third ventricle. $\boldsymbol{N}, \mathbf{0}$, In wild-type embryos at stage 27 (E5) and stage 31 (E7) Shh mRNA is not expressed at the floor of the third ventricle adjacent to the optic chiasm, although it is expressed laterally (on, optic nerve). $\boldsymbol{P}$, At stage 31 (E7) in eyeless embryos the pattern of Shh mRNA expression was not altered significantly. Scale bars: $\boldsymbol{A}, \boldsymbol{B}, \boldsymbol{M}, \mathbf{O}, \boldsymbol{P}, 100 \mu \mathrm{m} ; \boldsymbol{C}-\boldsymbol{H}, \boldsymbol{K}, \boldsymbol{L}, \mathbf{N}, 50 \mu \mathrm{m}$. 

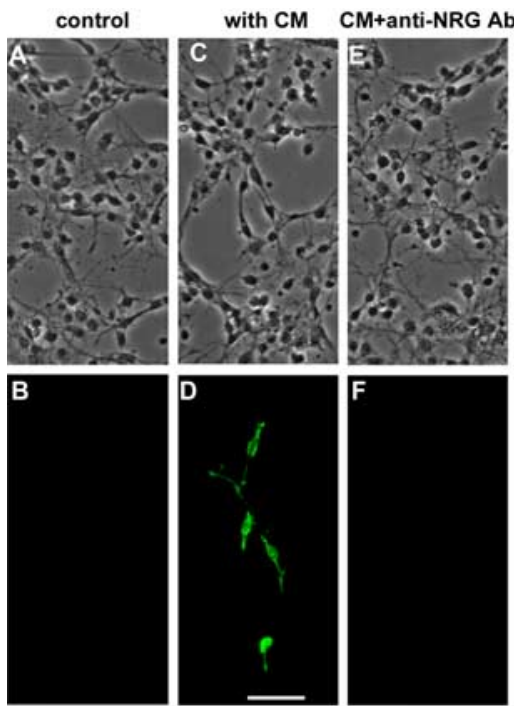

control
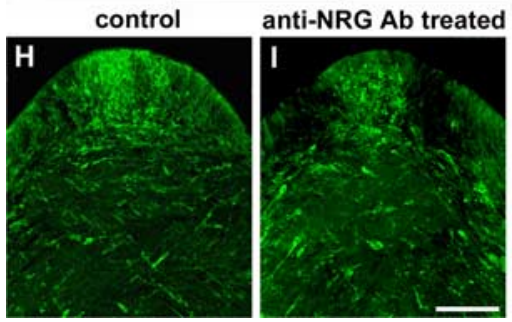
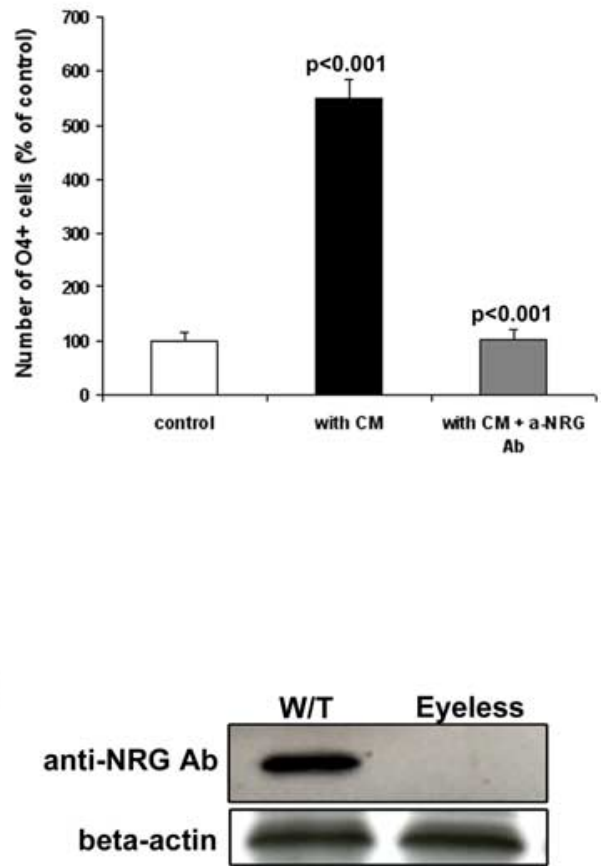

Figure 7. Retinal-derived neuregulin is required for normal OPC appearance. $\boldsymbol{A}-\boldsymbol{F}$, The ability of retinal conditioned medium to induce OPCs is blocked by NRG inhibitors. $\boldsymbol{A}, \boldsymbol{B}$, Control cultures of dorsal spinal cord contain few OPCS. C, D, OPCs are strongly induced by retinal CM. $\boldsymbol{E}, \boldsymbol{F}$, This induction is blocked with function-blocking anti-NRG antibody. $\mathbf{G}$, Quantification of $04^{+}$cells in cultures with different treatments. Error bars represent SD. $\boldsymbol{H}, \boldsymbol{I}$, Inhibition of NRG signaling between stage 21 (E3) and stage 29 (E6) significantly reduces the number of OPCs that develop at the floor of the third ventricle at stage 31 (E7). $\boldsymbol{H}$ shows a control animal, and I shows an anti-NRG-treated animal. $J$, The expression of NRG at the floor of the third ventricle is dependent on optic projections and is lost in eyeless animals. Scale bars (in $D, I$ ): $50 \mu \mathrm{m}$.

reduced proliferation of retinal progenitors (Burmeister et al., 1996) and that lack an optic nerve (Theiler et al., 1976; Robb et al., 1978; Silver and Robb, 1979). In wild-type mice a group of Olig2 ${ }^{+}$presumptive OPCs was detected at E15.5 in the floor of the third ventricle dorsal to the developing optic chiasm and optic nerves. Sections either rostral or caudal to the optic chiasm contained no Olig2 ${ }^{+}$cells at the ventral midline (Fig. $8 A$ ), suggesting that OPCs are induced by retinal axons. Consistent with this notion, in $o r^{J}$ mice that lack an optic nerve Olig2 ${ }^{+}$cells were absent from the ventral midline at the equivalent level of the optic chiasm (Fig. $8 \mathrm{~B}$ ). Furthermore, in vitro culture of the explants of the floor of the third ventricle also demonstrated a dramatic reduction of ${ }^{+}{ }^{+}$cells in or $^{J}$ mice as compared with wild-type mice (data not shown).

\section{Discussion}

Oligodendrocyte precursors arise in specific locations of the neural tube during development; however, the cellular interactions mediating their initial appearance are unknown. In the avian optic nerve oligodendrocytes develop from OPCs at the ventral midline of the third ventricle, and here we show that the appearance of these founder cells is dependent on RGC axons. Retinal cell bodies and their processes induce OPCs in responsive tissues, and this induction requires Shh and NRG signaling. In vivo, blocking Shh or NRG signaling inhibits oligodendrocyte development throughout the CNS, whereas removal of the eyes before optic axon growth results in a selective loss of OPCs in the floor of the third ventricle and a local reduction in Shh and NRG expression. On the basis of these observations we propose that extension of RGC axons to the chiasm region induces cells in the overlying floor of the third ventricle to commit to the oligodendrocyte lineage; the progeny of these cells subsequently populate and myelinate the optic nerve. The dramatic reduction of OPCs in the or mice suggests that the dependence on axonal cues for the development of optic nerve OPCs is a general phenomenon in the development of the visual system.

The interactions between axons and OPCs are critical throughout the development of oligodendrocytes. In the optic nerve the axons modulate the later stages of OPC development and establish the appropriate number of oligodendrocytes to ensure effective myelination (Barres and Raff, 1994). For example, transection of the postnatal rat optic nerve dramatically reduces the number of axons in the nerve, and the number of oligodendrocytes also is reduced dramatically (David et al., 1984). Likewise, in transgenic animals in which RGC numbers are elevated, there is a concomitant increase in the number of oligodendrocytes (Burne et al., 1996). This axonal regulation of oligodendrocyte cell number most likely reflects the activity of a number of different survival and growth factors, including PDGF, which is a major mitogen and survival factor for cells of the oligodendrocyte lineage (Calver et al., 1998). In transgenic animals expressing elevated PDGF excess the OPCs are generated, but the numbers normalize during development (Calver et al., 1998). Likewise, elevation of PDGF levels in the optic nerve results in increased numbers of oligodendrocyte lineage cells (Noble et al., 1988). Establishment of the appropriate number of mature oligodendrocytes reflects the control of apoptotic cell death (Raff et al., 1993), mediated by competition for limiting levels of survival factors supplied by adjacent axons (Barres and Raff, 1994). Whether the initial induction of OPCs in the third ventricle floor by optic axons represents suppression of cell death is unclear. No significant increase in apoptosis was detected in eyeless animals; however, the number of cells potentially affected is relatively small, and this CNS region is characterized by relatively high levels of cell death in normal animals (Silver et al., 1987). Alternatively, ingrowth of optic axons might promote elevated levels of proliferation of preexisting OPCs in the floor of the third ventricle. This is unlikely, however, because in normal animals the earliest detectable OPCs in the third ventricle floor have low levels of proliferation when compared with cells in the optic nerve (Ono et al., 2001). Furthermore, bromodeoxyuridine (BrdU) incorporation studies have failed to detect a significant change in proliferating cells after eye removal as compared with normal animals. Together, these data raise the possibility that the role of optic axons is to promote instructively the commitment of neuroepithelial cells to the oligodendrocyte lineage.

The finding that axonally derived cues or innervation modu- 

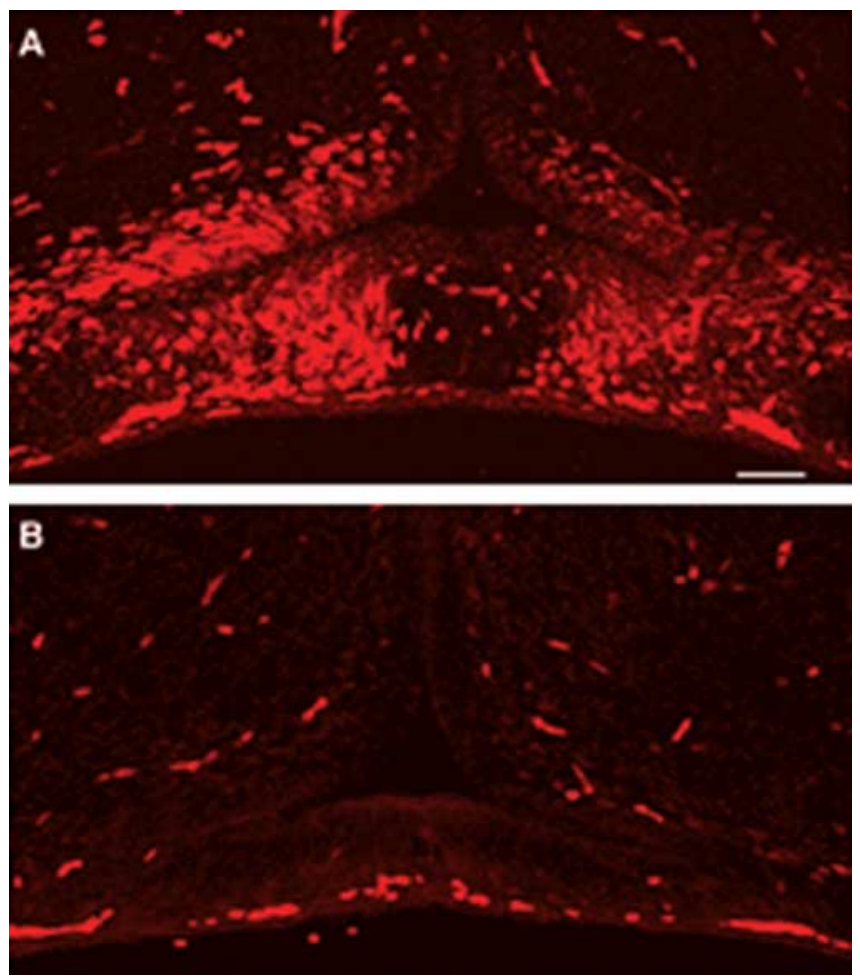

Figure 8. The appearance of mouse optic nerve oligodendrocyte precursors requires RGC innervation. $A$, In wild-type mice, a spatially distinct group of 0 lig ${ }^{+}$cells is present in the floor of the third ventricle immediately dorsal to the developing optic chiasm and optic nerves at E15.5. Sections either rostral or caudal to the optic chiasm contain no 0 lig $2^{+}$cells at the ventral midline. $\boldsymbol{B}$, In or mutant animals that fail to develop a normal retina and optic nerve, the Olig ${ }^{+}$cells are absent from the ventral midline at the level of the residual optic chiasm. Scale bar, $50 \mu \mathrm{m}$.

lates target cell fate is not restricted to the oligodendrocyte lineage. In Drosophila the growth of optic axons to the brain stimulates neurogenesis in the visual centers (Huang and Kunes, 1996). In the periphery the acquisition of fast or slow muscle phenotype is modulated by the nature of the innervating neurons (Windisch et al., 1998), whereas innervation of skeletal muscle results in multiple molecular responses, including clustering of acetylcholine receptors and assembly of the postsynaptic machinery (Role et al., 1985; McMahan, 1990; Gautam et al., 1996).

The molecular mechanisms mediating axonal interactions with their target cells are shared in several different systems, with the outcomes dependent on the interacting cells. In Drosophila the $h h$ signaling mediates the effects of the optic axons on subsequent brain development (Huang and Kunes, 1996). Shh is also important in a variety of tissue patterning, including lung development and limb formation (Bellusci et al., 1997; Dillon et al., 2003). In the spinal cord Shh is a ventralizing signal essential for the formation of motor neurons and other ventrally derived cells, including the majority of oligodendrocytes (Miller, 2002; Rowitch, 2004). In such caudal regions Shh secreted from notochord and floor plate cells was thought to induce a cell characterized by the expression of the transcription factor Olig2 that initially generated motor neurons and subsequently the OPCs (Lu et al., 2000; Zhou et al., 2000). More recent studies, however, suggest that the appearance of oligodendrocyte precursors and the role of Olig ${ }^{+}$cells are more complex. Although the ancestors to both motor neurons and oligodendrocytes transiently express Olig2, they apparently are unrelated (Mukouyama et al., 2006; Wu et al.,
2006). These data are more consistent with an early segregation of neuron and glial lineages as implied by in vitro studies (Noble et al., 2004) and suggest that changes in local cell-cell interactions (Park and Appel, 2003) or expression of transcription factors upstream of Olig2 and Nkx2.2 (Zhou et al., 2001) control early cell fate choices in this region of the CNS. The subsequent development of OPCs is dependent on the expression of Shh after the majority of motor neurons is formed (Orentas et al., 1999). In the induction of optic nerve OPCs Shh also appears to be important at multiple stages. The initial dorsoventral polarization of the third ventricle is dependent on Shh signaling (Ekker et al., 1995). The continued expression of Shh in the ventral midline acts as a chemoattractant for axonal growth (Charron et al., 2003) and specifically RGCs in the visual system (Trousse et al., 2001). Retinal ganglia cells express $S h h$, and its release from axons promotes optic nerve astrocyte precursor proliferation (Wallace and Raff, 1999). During the induction of OPCs both the in vitro and the timing of the in vivo data suggest a direct effect of the axonalderived Shh in OPC induction. On the basis of these observations we propose that $S h h$ has several specific roles in the development of the ventral midline, which culminates with the induction of OPCs from neuroepithelial cells by appropriately targeted retinal axon growth.

The induction of optic nerve OPCs by retinal axons is dependent on multiple molecular cues. Blocking NRG signaling inhibits the appearance of retinal-induced OPCs. Previous studies have implicated NRG in the regulation of different stages of OPC development. For example, NRG is required for early OPC development (Vartanian et al., 1999) and promotes the survival of mature OPCs (Fernandez et al., 2000). The differential developmental dependence on NRG signaling is more evident in the PNS where NRG promotes neural crest stem cells to glial lineage at E10.5 (Shah et al., 1996), enhances the survival of Schwann cell precursors at E15-E16 (Dong et al., 1995), and stimulates proliferation of mature Schwann cells at postnatal day 0-1 (Marchionni et al., 1993; Levi et al., 1995). Whether this NRG has to be derived axonally is unclear, although axonal NRG levels recently have been demonstrated to regulate myelination directly by Schwann cells (Michailov et al., 2004). Our studies suggest that, although both Shh and NRG are required for the appearance of optic nerve OPCs, they may not be sufficient for the commitment of neural epithelial cells to the oligodendrocyte lineage. For example, retinal conditioned medium effectively induces OPCs in dorsal spinal cord cultures, whereas the addition of soluble Shh or NRG singly or in combination does not, although they are functional in other systems (Vartanian et al., 1997). It may be either that additional molecules such as neurotransmitters like glutamate (Yuan et al., 1998) are released by retinal cells or that the ligands have to be presented to responsive cells in a precise manner. One possibility is that, because both Shh and NRG bind extracellular matrix (ECM) components, both axonal signaling and conditioned medium effects may depend on neuronalderived ECM (ffrench-Constant et al., 1988).

Eye removal dramatically reduced the appearance of oligodendrocytes at the ventral midline; however, a small population of cells remained in all experimental embryos. Several explanations may account for these cells. Both spinal cord and forebrain contain multiple sources of OPCs that differ in inductive cues (Kessaris et al., 2006), and in spinal cord ventrally, but not dorsally, derived cells are dependent on Shh (Cai et al., 2005; Vallstedt et al., 2005). Such diversity seems unlikely to account for the OPCs remaining after eye removal, because they were eliminated totally by cyclopamine treatment. More likely, the residual cells 
result from axonal signaling from nasal retinal axons that escaped resection or other axons that project close to the source. For example, in rodents the origin of OPCs has been termed "the knot," and olfactory axons project close to its caudal boundary (Schwob and Price, 1984).

Axonal regulation of OPC induction may have important implications for myelin repair in demyelinating diseases such as multiple sclerosis (MS). In the adult CNS the recruitment of OPCs from adult neural stem cells may depend on local axonal cues, and loss of axonal integrity (Chang et al., 2002) may contribute to the ultimate failure of myelin repair in some MS lesions.

\section{References}

Austin CP, Feldman DE, Ida Jr JA, Cepko CL (1995) Vertebrate retinal ganglion cells are selected from competent progenitors by the action of Notch. Development 121:3637-3650.

Barres BA, Raff MC (1994) Control of oligodendrocyte number in the developing rat optic nerve. Neuron 12:935-942.

Bellusci S, Furuta Y, Rush MG, Henderson R, Winnier G, Hogan BL (1997) Involvement of sonic hedgehog $(S h h)$ in mouse embryonic lung growth and morphogenesis. Development 124:53-63.

Bermingham-McDonogh O, McCabe KL, Reh TA (1996) Effects of GGF/ neuregulins on neuronal survival and neurite outgrowth correlate with erbB2/neu expression in developing rat retina. Development 122:1427-1438.

Brady-Kalnay SM, Rimm DL, Tonks NK (1995) Receptor protein tyrosine phosphatase PTP $\mu$ associates with cadherins and catenins in vivo. J Cell Biol 130:977-986.

Briscoe J, Sussel L, Serup P, Hartigan-O'Connor D, Jessell TM, Rubenstein JL, Ericson J (1999) Homeobox gene Nkx2.2 and specification of neuronal identity by graded Sonic hedgehog signaling. Nature 398:622-627.

Burmeister M, Novak J, Liang MY, Basu S, Ploder L, Hawes NL, Vidgen D, Hoover F, Goldman D, Kalnins VI, Roderick TH, Taylor BA, Hankin MH, McInnes RR (1996) Ocular retardation mouse caused by Chx10 homeobox null allele: impaired retinal progenitor proliferation and bipolar cell differentiation. Nat Genet 12:376-384

Burne JF, Staple JK, Raff MC (1996) Glial cells are increased proportionally in transgenic optic nerves with increased numbers of axons. J Neurosci 16:2064-2073.

Burns AJ, Douarin NM (1998) The sacral neural crest contributes neurons and glia to the post-umbilical gut: spatiotemporal analysis of the development of the enteric nervous system. Development 125:4335-4347.

Cai J, Qi Y, Hu X, Tan M, Liu Z, Zhang J, Li Q, Sander M, Qiu M (2005) Generation of oligodendrocyte precursor cells from mouse dorsal spinal cord independent of Nkx6 regulation and Shh signaling. Neuron 45:41-53.

Calver AR, Hall AC, Yu WP, Walsh FS, Heath JK, Betsholtz C, Richardson WD (1998) Oligodendrocyte population dynamics and the role of PDGF in vivo. Neuron 20:869-882.

Campenot RB (1977) Local control of neurite development by nerve growth factor. Proc Natl Acad Sci USA 74:4516-4519.

Canoll PD, Musacchio JM, Hardy R, Reynolds R, Marchionni MA, Salzer JL (1996) GGF/neuregulin is a neuronal signal that promotes the proliferation and survival and inhibits the differentiation of oligodendrocyte progenitors. Neuron 17:229-243.

Canoll PD, Kraemer R, Teng KK, Marchionni MA, Salzer JL (1999) GGF/ neuregulin induces a phenotypic reversion of oligodendrocytes. Mol Cell Neurosci 13:79-94.

Chandran S, Kato H, Gerreli D, Compston A, Svendsen CN, Allen ND (2003) FGF-dependent generation of oligodendrocytes by a hedgehogindependent pathway. Development 130:6599-6609.

Chang A, Tourtellotte WW, Rudick R, Trapp BD (2002) Premyelinating oligodendrocytes in chronic lesions of multiple sclerosis. N Engl J Med 346:165-173.

Charron F, Stein E, Jeong J, McMahon AP, Tessier-Lavigne M (2003) The morphogen Sonic hedgehog is an axonal chemoattractant that collaborates with Netrin-1 in midline axon guidance. Cell 113:11-23.

Dale JK, Vesque C, Lints TJ, Sampath TK, Furley A, Dodd J, Placzek M (1997) Cooperation of BMP7 and SHH in the induction of forebrain ventral midline cells by prechordal mesoderm. Cell 90:257-269.
David S, Miller RH, Patel R, Raff MC (1984) Effects of neonatal transection on glial cell development in the rat optic nerve: evidence that the oligodendrocyte-type 2 astrocyte cell lineage depends on axons for its survival. J Neurocytol 13:961-974.

Dillon R, Gadgil C, Othmer HG (2003) Short- and long-range effects of Sonic hedgehog in limb development. Proc Natl Acad Sci USA 100:10152-10157.

Dong Z, Brennan A, Liu N, Yarden Y, Lefkowitz G, Mirsky R, Jessen KR (1995) Neu differentiation factor is a neuron-glia signal and regulates survival, proliferation, and maturation of rat Schwann cell precursors. Neuron 15:585-596.

Drazba J, Pierce M, Lemmon V (1991) Studies of the developing chick retina using monoclonal antibody $8 \mathrm{~A} 2$ that recognizes a novel set of gangliosides. Dev Biol 145:154-163.

Ekker SC, Ungar AR, Greenstein P, von Kessler DP, Porter JA, Moon RT, Beachy PA (1995) Patterning activities of vertebrate hedgehog proteins in the developing eye and brain. Curr Biol 5:944-955.

Fernandez PA, Tang DG, Cheng L, Prochiantz A, Mudge AW, Raff MC (2000) Evidence that axon-derived neuregulin promotes oligodendrocyte survival in the developing rat optic nerve. Neuron 28:81-90.

ffrench-Constant C, Miller RH, Burne JF, Raff MC (1988) Evidence that migratory oligodendrocyte-type 2 astrocyte $(\mathrm{O}-2 \mathrm{~A})$ progenitor cells are kept out of the rat retina by a barrier at the eye-end of the optic nerve. J Neurocytol 17:13-25.

Gassmann M, Lemke G (1997) Neuregulins and neuregulin receptors in neural development. Curr Opin Neurobiol 7:87-92.

Gautam M, Noakes PG, Moscoso L, Rupp F, Scheller RH, Merlie JP, Sanes JR (1996) Defective neuromuscular synaptogenesis in agrin-deficient mutant mice. Cell 85:525-535.

Halfter W (1987) Anterograde tracing of retinal axons in the avian embryo with low molecular weight derivatives of biotin. Dev Biol 119:322-335.

Huang Z, Kunes S (1996) Hedgehog, transmitted along retinal axons, triggers neurogenesis in the developing visual centers of the Drosophila brain. Cell 86:411-422.

Kessaris N, Fogarty M, Iannarelli P, Grist M, Wegner M, Richardson WD (2006) Competing waves of oligodendrocytes in the forebrain and postnatal elimination of an embryonic lineage. Nat Neurosci 9:173-179.

Levi AD, Bunge RP, Lofgren JA, Meima L, Hefti F, Nikolics K, Sliwkowski MX (1995) The influence of heregulins on human Schwann cell proliferation. J Neurosci 15:1329-1340.

Loeb JA, Khurana TS, Robbins JT, Yee AG, Fischbach GD (1999) Expression patterns of transmembrane and released forms of neuregulin during spinal cord and neuromuscular synapse development. Development 126:781-791.

Lu QR, Yuk D, Alberta JA, Zhu Z, Pawlitzky I, Chan J, McMahon AP, Stiles CD, Rowitch DH (2000) Sonic hedgehog-regulated oligodendrocyte lineage genes encoding bHLH proteins in the mammalian central nervous system. Neuron 25:317-329.

Marchionni MA, Goodearl AD, Chen MS, Bermingham-McDonogh O, Kirk C, Hendricks M, Danehy F, Misumi D, Sudhalter J, Kobayashi K, Wroblewski D, Lynch C, Baldassare M, Hiles I, Davis JB, Hsuan JJ, Totty NF, Otsu M, McBurney RN, Waterfield MD, Stroobant P, Gwynne D (1993) Glial growth factors are alternatively spliced erbB2 ligands expressed in the nervous system. Nature 362:312-318.

McCabe KL, Gunther EC, Reh TA (1999) The development of the pattern of retinal ganglion cells in the chick retina: mechanisms that control differentiation. Development 126:5713-5724.

McMahan UJ (1990) The agrin hypothesis. Cold Spring Harb Symp Quant Biol 55:407-418.

Meyer D, Birchmeier C (1994) Distinct isoforms of neuregulin are expressed in mesenchymal and neuronal cells during mouse development. Proc Natl Acad Sci USA 91:1064-1068.

Michailov GV, Sereda MW, Brinkmann BG, Fischer TM, Haug B, Birchmeier C, Role L, Lai C, Schwab MH, Nave KA (2004) Axonal neuregulin-1 regulates myelin sheath thickness. Science 304:700-703.

Miller RH (1996) Oligodendrocyte origins. Trends Neurosci 19:92-96.

Miller RH (2002) Regulation of oligodendrocyte development in the vertebrate CNS. Prog Neurobiol 67:451-467.

Miller RH, Payne J, Milner L, Zhang H, Orentas DM (1997) Spinal cord oligodendrocytes develop from a limited number of migratory highly proliferative precursors. J Neurosci Res 50:157-168.

Mukouyama YS, Deneen B, Lukaszewicz A, Novitch BG, Wichterle H, Jessell 
TM, Anderson DJ (2006) Olig2 ${ }^{+}$neuroepithelial motoneuron progenitors are not multipotent stem cells in vivo. Proc Natl Acad Sci USA 103:1551-1556.

Nery S, Wichterle H, Fishell G (2001) Sonic hedgehog contributes to oligodendrocyte specification in the mammalian forebrain. Development 128:527-540.

Noble M, Murray K, Stroobant P, Waterfield MD, Riddle P (1988) Plateletderived growth factor promotes division and motility and inhibits premature differentiation of the oligodendrocyte/type- 2 astrocyte progenitor cell. Nature 333:560-562.

Noble M, Proschel C, Mayer-Proschel M (2004) Getting a GR(i)P on oligodendrocyte development. Dev Biol 265:33-52.

Ono K, Bansal R, Payne J, Rutishauser U, Miller RH (1995) Early development and dispersal of oligodendrocyte precursors in the embryonic chick spinal cord. Development 121:1743-1754.

Ono K, Yasui Y, Rutishauser U, Miller RH (1997) Focal ventricular origin and migration of oligodendrocyte precursors into the chick optic nerve. Neuron 19:283-292.

Ono K, Tsumori T, Yokota S, Yasui Y (2001) Extensive proliferation of oligodendrocyte precursors in the parenchyma of the embryonic chick central nervous system. Dev Biol 231:77-86.

Orentas DM, Miller RH (1996) A novel form of migration of glial precursors. Glia 16:27-39.

Orentas DM, Hayes JE, Dyer KL, Miller RH (1999) Sonic hedgehog signaling is required during the appearance of spinal cord oligodendrocyte precursors. Development 126:2419-2429.

Park HC, Appel B (2003) Delta-Notch signaling regulates oligodendrocyte specification. Development 130:3747-3755.

Perez SE, Rebelo S, Anderson DJ (1999) Early specification of sensory neuron fate revealed by expression and function of neurogenins in the chick embryo. Development 126:1715-1728.

Prada C, Medina JI, Lopez R, Genis-Galvez JM, Prada FA (1992) Development of retinal displaced ganglion cells in the chick: neurogenesis and morphogenesis. J Neurosci 12:3781-3788.

Raff MC, Barres BA, Burne JF, Coles HS, Ishizaki Y, Jacobson MD (1993) Programmed cell death and the control of cell survival: lessons from the nervous system. Science 262:695-700.

Rager GH (1980) Development of the retinotectal projection in the chicken. Adv Anat Embryol Cell Biol 63[I-VIII]1-90.

Robb RM, Silver J, Sullivan RT (1978) Ocular retardation (or) in the mouse. Invest Ophthalmol Vis Sci 17:468-473.

Role LW, Matossian VR, O’Brien RJ, Fischbach GD (1985) On the mechanism of acetylcholine receptor accumulation at newly formed synapses on chick myotubes. J Neurosci 5:2197-2204.

Rowitch DH (2004) Glial specification in the vertebrate neural tube. Nat Rev Neurosci 5:409-419.

Schaeren-Wiemers N, Gerfin-Moser A (1993) A single protocol to detect transcripts of various types and expression levels in neural tissue and cultured cells: in situ hybridization using digoxigenin-labeled cRNA probes. Histochemistry 100:431-440.

Schwob JE, Price JL (1984) The development of axonal connections in the central olfactory system of rats. J Comp Neurol 223:177-202.

Shah NM, Groves AK, Anderson DJ (1996) Alternative neural crest cell fates are instructively promoted by TGF $\beta$ superfamily members. Cell 85:331-343.

Silver J, Robb RM (1979) Studies on the development of the eye cup and optic nerve in normal mice and in mutants with congenital optic nerve aplasia. Dev Biol 68:175-190.

Silver J, Poston M, Rutishauser U (1987) Axon pathway boundaries in the developing brain. I. Cellular and molecular determinants that separate the optic and olfactory projections. J Neurosci 7:2264-2272.
Small RK, Riddle P, Noble M (1987) Evidence for migration of oligodendrocyte type- 2 astrocyte progenitor cells into the developing rat optic nerve. Nature 328:155-157.

Snow RL, Robson JA (1994) Ganglion cell neurogenesis, migration, and early differentiation in the chick retina. Neuroscience 58:399-409.

Sommer L, Ma Q, Anderson DJ (1996) Neurogenins, a novel family of atonal-related bHLH transcription factors, are putative mammalian neuronal determination genes that reveal progenitor cell heterogeneity in the developing CNS and PNS. Mol Cell Neurosci 8:221-241.

Soula C, Danesin C, Kan P, Grob M, Poncet C, Cochard P (2001) Distinct sites of origin of oligodendrocytes and somatic motoneurons in the chick spinal cord: oligodendrocytes arise from $N k x 2.2$-expressing progenitors by a Shh-dependent mechanism. Development 128:1369-1379.

Spence SG, Robson JA (1989) An autoradiographic analysis of neurogenesis in the chick retina in vitro and in vivo. Neuroscience 32:801-812.

Stone DM, Hynes M, Armanini M, Swanson TA, Gu Q, Johnson RL, Scott MP, Pennica D, Goddard A, Phillips H, Noll M, Hooper JE, de Sauvage F, Rosenthal A (1996) The tumour-suppressor gene patched encodes a candidate receptor for Sonic hedgehog. Nature 384:129-134.

Tanabe Y, Jessell TM (1996) Diversity and pattern in the developing spinal cord. Science 274:1115-1123.

Theiler K, Varnum DS, Nadeau JH, Stevens LC, Cagianut B (1976) A new allele of ocular retardation: early development and morphogenetic cell death. Anat Embryol (Berl) 150:85-97.

Trousse F, Marti E, Gruss P, Torres M, Bovolenta P (2001) Control of retinal ganglion cell axon growth: a new role for Sonic hedgehog. Development 128:3927-3936.

Vallstedt A, Klos JM, Ericson J (2005) Multiple dorsoventral origins of oligodendrocyte generation in the spinal cord and hindbrain. Neuron 45:55-67.

Vartanian T, Goodearl A, Viehover A, Fischbach G (1997) Axonal neuregulin signals cells of the oligodendrocyte lineage through activation of HER4 and Schwann cells through HER2 and HER3. J Cell Biol 137:211-220.

Vartanian T, Fischbach G, Miller R (1999) Failure of spinal cord oligodendrocyte development in mice lacking neuregulin. Proc Natl Acad Sci USA 96:731-735.

Wallace VA, Raff MC (1999) A role for Sonic hedgehog in axon-to-astrocyte signaling in the rodent optic nerve. Development 126:2901-2909.

Windisch A, Gundersen K, Szabolcs MJ, Gruber H, Lomo T (1998) Fast to slow transformation of denervated and electrically stimulated rat muscle. J Physiol (Lond) 510[Pt 2]:623-632.

Wordinger RJ, Agarwal R, Talati M, Fuller J, Lambert W, Clark AF (2002) Expression of bone morphogenetic proteins (BMP), BMP receptors, and BMP-associated proteins in human trabecular meshwork and optic nerve head cells and tissues. Mol Vis 8:241-250.

Wu S, Wu Y, Capecchi MR (2006) Motoneurons and oligodendrocytes are sequentially generated from neural stem cells but do not appear to share common lineage-restricted progenitors in vivo. Development 133:581-590.

Yuan X, Eisen AM, McBain CJ, Gallo V (1998) A role for glutamate and its receptors in the regulation of oligodendrocyte development in cerebellar tissue slices. Development 125:2901-2914.

Zhang XM, Yang XJ (2001) Regulation of retinal ganglion cell production by Sonic hedgehog. Development 128:943-957.

Zhou Q, Wang S, Anderson DJ (2000) Identification of a novel family of oligodendrocyte lineage-specific basic helix-loop-helix transcription factors. Neuron 25:331-343.

Zhou Q, Choi G, Anderson DJ (2001) The bHLH transcription factor Olig2 promotes oligodendrocyte differentiation in collaboration with $N k \times 2.2$. Neuron 31:791-807. 